\title{
Stimulation of insulin release by an organic calcium agonist
}

\author{
W.J. Malaisse and P.C.F. Mathias \\ Laboratory of Experimental Medicine, Brussels Free University, Brussels, Belgium
}

Summary. The calcium-agonist 4-[2-(difluoromethoxy)phenyl]-1,4,5,7-tetrahydro-2-methyl-5-oxo-furo[3,4-b]pyridine-3carboxylic acid ethylester provoked, in the $1.0-100 \mu \mathrm{mol} / 1$ range, a dose-related increase of glucose-stimulated insulin release by rat pancreatic islets. A fixed concentration of the drug $(50 \mu \mathrm{mol} / 1)$ caused a shift to the left of the sigmoidal curve relating insulin output to glucose concentration. The drug failed to affect insulin release evoked, in the absence of $\mathrm{Ca}^{2+}$, by the combination of $\mathrm{Ba}^{2+}$ and theophylline. The enhancing action of the calcium-agonist upon insulin release was rapid and sus- tained, and coincided with stimulation of both ${ }^{45} \mathrm{Ca}$ net uptake and ${ }^{45} \mathrm{Ca}$ efflux, the latter phenomenon being abolished in the absence of extracellular $\mathrm{Ca}^{2+}$. It is concluded that the gating of Ca-channels, as presumably provoked by the calcium-agonist, simulates the stimulant action of glucose upon both $\mathrm{Ca}$ influx into and insulin release from the pancreatic islets.

Key words: Pancreatic islets, insulin release, calcium-agonist.
Recently, several compounds, which are chemically related to organic calcium-antagonists, were found to act as calcium-agonists, apparently causing the gating of calcium-channels and stimulation of calcium-dependent physiological processes [1-5]. In the present study, we have explored the effect of one of these agents, 4-[2-(difluoromethoxy)phenyl]-1,4,5,7-tetrahydro-2-methyl-5-oxo-furo[3,4-b]pyridine-3-carboxylic acid ethylester, upon calcium fluxes and insulin release in rat pancreatic islets.

\section{Materials and methods}

The drug 4-[2-(difluoromethoxy)phenyl]-1,4,5,7-tetrahydro-2-methyl5-oxo-furo[3,4-b]pyridine-3-carboxylic acid ethylester (CGP 28392) was kindly provided by Dr. L. Best (Department of Pharmacology, University of London), and solubilized in dimethylsulphoxide at an initial concentration of 25 or $50 \mathrm{mmol} / \mathrm{l}$. The same concentration of the solvent (not exceeding $2 \mu \mathrm{l} / \mathrm{ml}$ ) was added to control incubation media. At this concentration, dimethylsulphoxide fails to affect islet function [6].

All experiments were conducted with islets isolated from the pancreas of fed albino rats [7]. The methods used to measure insulin release [8] and ${ }^{45} \mathrm{Ca}$ net uptake [9] in static incubations and insulin release [10] and ${ }^{45} \mathrm{Ca}$ fractional outflow rate [11] from prelabelled perifused islets were already described in the cited references. Briefly insulin release was measured by incubating for 90 min groups of eight islets each in $1.0 \mathrm{ml}$ of bicarbonate-buffered media. The net uptake of ${ }^{45} \mathrm{Ca}$ was also measured in groups of eight islets over $90 \mathrm{~min}$ incubation, followed by repeated washes to remove extracellular ${ }^{45} \mathrm{Ca}$. In the perifusion experiments, the islets were prelabelled for $60 \mathrm{~min}$ in the presence of ${ }^{45} \mathrm{Ca}$ and D-glucose $(16.7 \mathrm{mmol} / \mathrm{l})$ and then placed in the perifusion chamber.

\section{Statistical analyses}

All results are expressed as mean \pm SEM together with the number of individual observations and statistical significance of differences between control and test values, as assessed by Student's t-test.

\section{Results}

\section{Secretory data}

Glucose (2.8 to $16.7 \mathrm{mmol} / \mathrm{l})$ caused a dose-related increase in insulin output (Table 1). At a concentration of $50 \mu \mathrm{mol} / 1, \mathrm{CGP} 28392$ augmented insulin output in the

Table 1. Effect of CGP 28392 upon glucose-induced insulin release

\begin{tabular}{|c|c|c|c|}
\hline \multirow{2}{*}{$\begin{array}{l}\text { D-glucose } \\
(\mathrm{mmol} / \mathrm{l})\end{array}$} & \multicolumn{2}{|c|}{ Insulin output $(\mu \mathrm{U} / 90 \mathrm{~min}$ per islet) } & \multirow[t]{2}{*}{$p$} \\
\hline & Control & CGP $28392(50 \mu \mathrm{mol} / \mathrm{l})$ & \\
\hline 2.8 & $12.8 \pm 1.5(24)$ & $15.1 \pm 1.3(24)$ & NS \\
\hline 5.6 & $23.7 \pm 2.3(24)$ & $69.9 \pm 4.9(24)$ & $<0.001$ \\
\hline 7.0 & $55.1 \pm 3.7(30)$ & $100.5 \pm 9.9(30)$ & $<0.001$ \\
\hline 11.1 & $158.6 \pm 8.7(35)$ & $207.1 \pm 10.7(35)$ & $<0.001$ \\
\hline 16.7 & $261.5 \pm 11.9(35)$ & $275.4 \pm 11.0(35)$ & NS \\
\hline
\end{tabular}

Results expressed as mean \pm SEM with number of observations in parentheses 


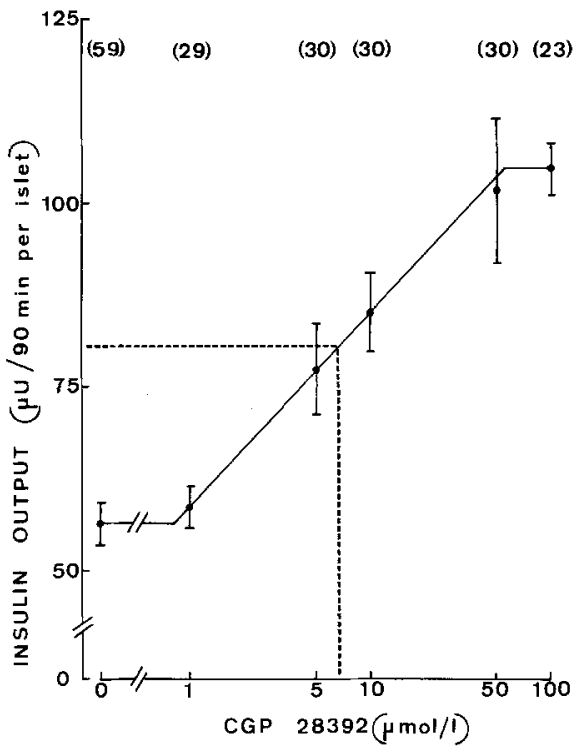

Fig. 1. Effect of increasing concentrations of CGP 28392 (logarithmic scale) upon insulin release from islets incubated in the presence of $D$ glucose $(7 \mathrm{mmol} / 1)$. Mean $\pm \mathrm{SEM}$ values are shown with the number of individual measurements in parentheses. ----: the concentration of CGP 28392 causing a half-maximal increment in insulin output

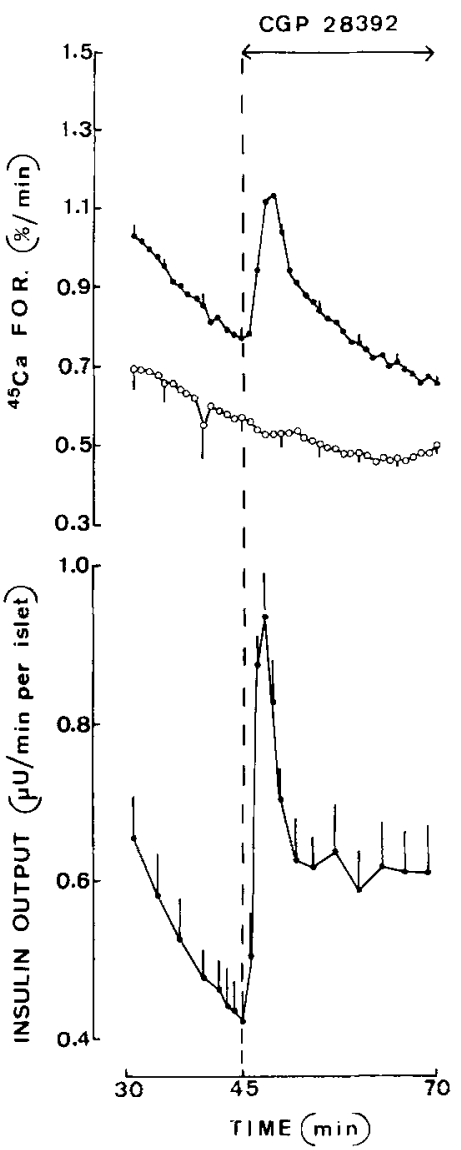

Fig. 2. Effect of CGP $28392(25 \mu \mathrm{mol} / 1)$ administered from min 46 to 70 upon ${ }^{45} \mathrm{Ca}$ fractional outflow rate (FOR; upper panel) and insulin release (lower panel) from prelabelled pancreatic islets perifused in the presence of $D$-glucose $(7.0 \mathrm{mmol} / \mathrm{l})$. The experiments were performed either at normal $\mathrm{Ca}^{2+}$ concentration $(1.0 \mathrm{mmol} / \mathrm{l}$; closed circles) or in the absence of $\mathrm{Ca}^{2+}$ and presence of EGTA $(0.5 \mathrm{mmol} / 1$; open circles). Mean \pm SEM values refer to four individual experiments in each case presence of D-glucose in the $5.6-11.1 \mathrm{mmol} / 1 \mathrm{range}$, but failed to affect significantly insulin release at either a non-stimulatory concentration of glucose $(2.8 \mathrm{mmol} /$ 1) or at a high concentration of the sugar $(16.7 \mathrm{mmol} / \mathrm{l})$ causing close-to-maximal stimulation of secretion. Thus, the effect of CGP 28392 upon glucose-stimulated insulin release resulted in a shift to the left of the sigmoidal curve relating insulin output to the ambient glucose concentration.

At a fixed concentration of D-glucose $(7.0 \mathrm{mmol} / \mathrm{l})$, the effect of CGP 28392 upon insulin release was doserelated in the $1-100 \mu \mathrm{mol} / 1$ range, with a half-maximal response at a drug concentration close to $7 \mu \mathrm{mol} / 1$ (Fig. 1). However, when the concentration of CGP 28392 was raised to $0.5 \mathrm{mmol} / \mathrm{l}$, the release of insulin evoked by D-glucose $(7.0 \mathrm{mmol} / \mathrm{l})$ was decreased to $55.9 \pm 12.2 \%(n=22)$ of the corresponding mean control value. At a glucose concentration of $7.0 \mathrm{mmol} / 1$, the secretory response to CGP $28392(25 \mathrm{umol} / \mathrm{l})$ was a rapid, biphasic and sustained phenomenon (Fig.2). The stimulant action of CGP 28392 upon insulin output was already evident after $1 \mathrm{~min}$ and reached its peak value during min 3 of exposure to the drug. A different picture was seen when the same experiments were repeated at a lower concentration of glucose $(2.8 \mathrm{mmol} / 1)$ and a somewhat higher concentration of CGP 28392 $(50 \mu \mathrm{mol} / 1)$. In such a case, the drug only caused a modest increase in insulin output, which reached its peak value after 9 min exposure to CGP 28392. After correction for basal output $(25 \pm 12 \mathrm{nU} / \mathrm{min}$ per islet $)$, the drug-induced increment in insulin output reached, at min 54 of perfusion, a peak value of $28 \pm 13 \mathrm{nU} / \mathrm{min}$ per islet and over $25 \mathrm{~min}$ stimulation averaged no more than $19 \pm 4 \mathrm{nU} / \mathrm{min}$ per islet ( $n=4$ in all cases).

The data summarized in Table 2 indicate that verapamil $(0.01 \mathrm{mmol} / \mathrm{l})$ inhibited to a greater relative extent the secretory response to D-glucose $(7.0 \mathrm{mmol} / \mathrm{l})$ than the increment in secretion attributable to CGP 28392 $(50 \mathrm{\mu mol} / 1)$. Indeed, relative to the appropriate control value, the inhibitory action of verapamil amounted to $75.4 \pm 4.6 \%$ in response to D-glucose and $42.9 \pm 14.6 \%$ in response to CGP 28392. CGP $28392(50 \mu \mathrm{mol} / \mathrm{l})$ failed to affect insulin release evoked, in the absence of $\mathrm{Ca}^{2+}$, by the association of $\mathrm{Ba}^{2+}$ and theophylline (Table 2).

\section{Ionic data}

In the presence of glucose $(7.0 \mathrm{mmol} / 1)$, CGP 28392 in the $5-100 \mathrm{umol} / 1$ range, stimulated ${ }^{45} \mathrm{Ca}$ net uptake by the islets (Table 3). At the lowest efficient concentration $(5 \mu \mathrm{mol} / \mathrm{l})$, CGP 28392 increased ${ }^{45} \mathrm{Ca}$ net uptake by $14.2 \pm 5.5 \%$ above the mean control value $(p<0.05)$. At a 20 -fold higher concentration $(100 \mathrm{umol} / 1)$, the relative increase in ${ }^{45} \mathrm{Ca}$ net uptake amounted to $35.1 \pm 7.5 \%$. In the presence of D-glucose $(7.0 \mathrm{mmol} / 1)$, a still higher concentration of CGP $28392(0.5 \mathrm{mmol} / 1)$ failed to enhance and actually inhibited ${ }^{45} \mathrm{Ca}$ net uptake. 
Table 2. Effect of CGP 28392 upon insulin release in the presence of different insulinotropic agents

\begin{tabular}{|c|c|c|c|c|c|c|}
\hline $\begin{array}{l}\text { D-glucose } \\
(\mathrm{mmol} / \mathrm{l})\end{array}$ & $\begin{array}{l}\mathrm{Ca}^{2+} \\
(\mathrm{mmol} / \mathrm{l})\end{array}$ & $\begin{array}{l}\mathrm{Ba}^{2+} \\
(\mathrm{mmol} / \mathrm{l})\end{array}$ & $\begin{array}{l}\text { Theophylline } \\
(\mathrm{mmol} / \mathrm{l})\end{array}$ & $\begin{array}{l}\text { Verapamil } \\
(\mathrm{mmol} / \mathrm{l})\end{array}$ & $\begin{array}{l}\text { CGP } 28392 \\
(\mathrm{mmol} / \mathrm{l})\end{array}$ & $\begin{array}{l}\text { Insulin output } \\
(\mu \mathrm{U} / 90 \text { min per islet })\end{array}$ \\
\hline 2.8 & 1.0 & - & - & - & - & $12.8 \pm 1.5(24)$ \\
\hline 7.0 & 1.0 & - & - & - & 0.05 & $76.1 \pm 4.7(24)$ \\
\hline 7.0 & 1.0 & - & - & 0.01 & - & $21.6 \pm 2.6(24)$ \\
\hline 7.0 & 1.0 & - & - & 0.01 & 0.05 & $36.8 \pm 2.8(24)$ \\
\hline- & - & 2.0 & 1.4 & - & - & $127.0 \pm 3.4(29)$ \\
\hline
\end{tabular}

Results expressed as mean \pm SEM with number of observations in parentheses

Table 3. Effect of CGP 28392 upon ${ }^{45} \mathrm{Ca}$ net uptake by islets incubated in the presence of D-glucose $(7.0 \mathrm{mmol} / 1)$

\begin{tabular}{ll}
\hline $\begin{array}{l}\text { CGP 28392 } \\
(\mu \mathrm{mol} / \mathrm{l})\end{array}$ & $\begin{array}{l}{ }^{45} \mathrm{Ca} \text { net uptake } \\
\text { (pmol/islet at 90th min) }\end{array}$ \\
\hline Nil & $2.53 \pm 0.08(47)$ \\
1 & $2.75 \pm 0.13(15)$ \\
5 & $2.89 \pm 0.14(15)$ \\
10 & $2.99 \pm 0.16(17)$ \\
50 & $3.05 \pm 0.15(17)$ \\
100 & $3.50 \pm 0.19(15)$ \\
500 & $1.82 \pm 0.09(15)$ \\
\hline
\end{tabular}

Results expressed as mean \pm SEM with number of observations in parentheses

At a fixed concentration of D-glucose $(7 \mathrm{mmol} / \mathrm{l})$ and increasing concentrations of CGP 28392 $(1.0-500 \mu \mathrm{mol} / \mathrm{l})$, there was a significant correlation between the mean values for ${ }^{45} \mathrm{Ca}$ uptake and insulin release $(r=0.932, n=7, p<0.01)$. The relationship between these two variables [9] suggested that, in excess of a threshold value for ${ }^{45} \mathrm{Ca}$ uptake close to $1.5 \mathrm{pmol} /$ islet (at min 90), the increment in insulin output relative to that in ${ }^{45} \mathrm{Ca}$ net uptake averaged $46 \mu \mathrm{U} / \mathrm{pmol}$.

When the islets were prelabelled with ${ }^{45} \mathrm{Ca}$ and placed in a perifusion chamber, CGP $28392(25 \mu \mathrm{mol} / \mathrm{l})$ provoked, in the presence of glucose $(7 \mathrm{mmol} / 1)$, a rapid increase in effluent radioactivity (Fig. 2). The latter increase was suppressed when the islets were perifused in the absence of extracellular $\mathrm{Ca}^{2+}$ and presence of EGTA $(0.5 \mathrm{mmol} / 1)$, suggesting that it corresponded to a process of exchange between influent ${ }^{40} \mathrm{Ca}$ and effluent ${ }^{45} \mathrm{Ca}$. Before CGP 28392 administration, the fractional outflow rate of ${ }^{45} \mathrm{Ca}$ from the islets exposed to glucose $(7.0 \mathrm{mmol} / 1)$ was lower in the absence than presence of extracellular $\mathrm{Ca}^{2+}(p<0.005$; Fig. 2). When these experiments were repeated at a lower glucose concentrations $(2.8 \mathrm{mmol} / \mathrm{l})$, the increment in ${ }^{45} \mathrm{Ca}$ fractional outflow rate evoked by CGP $28392(50 \mu \mathrm{mol} / \mathrm{l})$ in the presence of $\mathrm{Ca}^{2+}(1.0 \mathrm{mmol} / 1)$ was less marked and less rapid. Thus, the peak value in ${ }^{45} \mathrm{Ca}$ fractional outflow rate was reached $9 \mathrm{~min}$ after introduction of CGP 28392 and represented a mean increment of $0.047 \pm 0.006 \% / \mathrm{min}$ (paired difference between min 54 and 45) as distinct from $0.342 \pm 0.019 \% / \mathrm{min}$ in the experiments illustrated in Figure 2.

\section{Discussion}

The present results indicate that CGP 28392 reproduces the stimulant action of D-glucose upon $\mathrm{Ca}^{2+}$ entry into and insulin release from pancreatic islets. Thus, the calcium-agonist caused a shift to the left of the sigmoidal curve relating insulin output to glucose concentration. This coincided with stimulation of ${ }^{45} \mathrm{Ca}$ net uptake, which was measured in washed islets. The stimulation of ${ }^{45} \mathrm{Ca}$ net uptake was apparently attributable to facilitated Ca influx into the islet cells. Thus, CGP 28392 enhanced ${ }^{45} \mathrm{Ca}$ efflux from prelabelled islets, provided that $\mathrm{Ca}^{2+}$ was present in the perifusate. The drug failed to affect ${ }^{45} \mathrm{Ca}$ outflow from islets perifused in the absence of extracellular $\mathrm{Ca}^{2+}$, suggesting that it did not exert any primary effect upon either the intracellular handling or efflux of $\mathrm{Ca}^{2+}$. It is also unlikely that CGP 28392 acted upon a late event in the secretory sequence, since it failed to affect insulin release evoked, in the absence of $\mathrm{Ca}^{2+}$, by the combination of $\mathrm{Ba}^{2+}$ and theophylline. The latter process is currently attributed to an intracellular redistribution of $\mathrm{Ca}^{2+}$ in the islet cells $[12,13]$.

The calcium-agonist CGP 28392 was still able to augment insulin release in the presence of verapamil, which was used at a concentration sufficiently high to cause a severe inhibition of glucose-stimulated insulin release. We have recently reported that, under suitable experimental conditions, organic calcium-agonists may even protect the pancreatic B cell against the inhibitory action of chemically related calcium-antagonists [14].

It should be underlined that CGP 28392 markedly augmented glucose-stimulated insulin release, but exerted little effect upon secretion at a non-stimulating glucose concentration. This behaviour is not attributable to the use of an insufficient concentration of CGP 28392. Indeed, at much higher concentrations ( $\geqslant$ $0.5 \mathrm{mmol} / \mathrm{l}$ ), CGP 28392 inhibited glucose-stimulated insulin release. It is remarkable that a comparable situation was already observed with another calcium-agonist [14]. It is currently believed, especially from experiments performed at high concentrations of extracellular $\mathrm{K}^{+}$, that the depolarization of the plasma membrane and subsequent gating of voltage-sensitive $\mathrm{Ca}^{2+}$ channels is sufficient to provoke bioelectrical activity and in- 
sulin release, even when the islet cells are deprived of exogenous nutrient [15-17]. Therefore, the modest effect of CGP 28392 upon insulin release at a low glucose concentration could be taken as an indication that the drug is not quite as efficient as high $\mathrm{K}^{+}$in causing the gating of $\mathrm{Ca}$ channels. It is also conceivable that, at higher glucose concentrations, the sugar facilitates, by some biophysical effect, e.g. by fluidification of the plasma membrane [18], the access of CGP 28392 to or its effect upon the regulatory system involved in the gating or closing of calcium channels. Moreover, since it was recently reported that the prevailing effect of CGP 28392 is a prolongation of the mean open time of Ca channels in cultured cardiac cells [19], it is quite understandable that the drug exerted little effect at either low or very higher glucose concentrations, when spiking bioelectrical activity is either absent or continuous in the absence of the drug [20].

In conclusion, the present findings afford further support to the view that the gating of calcium channels represents an efficient modality for stimulation, or at least facilitation, of insulin release. This view should not be overlooked when considering alternative models of stimulus-secretion coupling, such as the mobilization of intracellular $\mathrm{Ca}^{2+}$ by inositol 1,4,5-triphosphate [21]. When taken in conjunction with previous observations $[14,22]$, the present findings also raise the question whether, in the process of nutrient-stimulated insulin release, endogenous dihydropyridine derivatives generated in the B-cell as a result of changes in redox state [23] participate in the remodelling of cationic fluxes.

Acknowledgements. The present work was supported by grants from the Belgian Foundation for Scientific Medical Research and Belgian Ministry of Scientific Policy. P.C.F.M. is a Research Fellow of the Conselho Nacional de Desenvolvimento Cientifico e Tecnologico (Brazil). We thank M.Mahy and J.Schoonheydt for technical assistance and C. Demesmaeker for secretarial help.

\section{References}

1. Schramm M, Thomas G, Towart R, Franckowiak G (1983) Novel dihydropyridines with positive inotropic action through activation of $\mathrm{Ca}^{2+}$ channels. Nature 303: 535-537

2. Thomas G, Schramm M, Franckowiak G (1983) Dihydropyridines that exert positive inotropic effects in isolated cardiac muscle: evidence for Ca channel modulation. Pharmacologist 25:206

3. Towart R, Schramm M, Kazda S (1983) Calcium agonism, a new pharmacological principle: effects of BAY K 8644 on the isolated rabbit aortic strip. Naunyn Schmiedeberg's Arch Pharmacol 324 (Suppl): R47

4. Erne P, Bürgisser E, Bühler FR, Dubach B, Kühnis H, Meier M, Rogg H (1984) Enhancement of calcium influx in human platelets by CGP 28392, a novel dihydropyridine. Biochem Biophys Res Commun 118: 842-847

5. Truog AG, Brunner H, Criscione L, Fallert M, Kühnis H, Meier M, Rogg H (1984) CGP 28392, a dihydropyridine $\mathrm{Ca}^{2+}$ entry stimulator. In: Rubin RP, Weiss G, Putney JW (eds) Calcium in biological systems. Plenum Press, New York (in press)

6. Levy J, Herchuelz A, Sener A, Malaisse-Lagae F, Malaisse WJ (1978) Cytochalasin B-induced impairment of glucose metabolism in islets of Langerhans. Endocrinology 98: 429-437

7. Lacy PE, Kostianovsky M (1967) Method for the isolation of intact islets of Langerhans from the rat pancreas. Diabetes 16: 35-42

8. Malaisse W, Brisson G, Malaisse-Lagae F (1970) The stimulus-secretion coupling of glucose-induced insulin release. I. Interaction of epinephrine and alkaline earth cations. $\mathrm{J}$ Lab Clin Med 76: 895-902

9. Malaisse-Lagae F, Malaisse WJ (1971) Stimulus-secretion coupling of glucose-induced insulin release. III. Uptake of ${ }^{45}$ calcium by isolated islets of Langerhans. Endocrinology 88: 72-80

10. Herchuelz A, Malaisse WJ (1978) Regulation of calcium fluxes in pancreatic islets. Dissociation between calcium and insulin release. J Physiol (London) 283: 409-424

11. Herchuelz A, Sener A, Malaisse WJ (1980) Regulation of calcium fluxes in rat pancreatic islets: calcium extrusion by sodium-calcium countertransport. J Membrane Biol 57: 1-12

12. Berggren PO, Andersson B, Hellman B (1982) Stimulation of the insulin secretory mechanism following barium accumulation in pancreatic $\beta$-cells. Biochim Biophys Acta 720: 320-328

13. Berggren PO, Andersson T, Hellman B (1983) The interaction between barium and calcium in $\beta$-cell-rich pancreatic islets. Biomed Res 4: 129-138

14. Malaisse-Lagae F, Mathias PCF, Malaisse WJ (1984) Gating and blocking of calcium channels by dihydropyridines in the pancreatic B-cell. Biochem Biophys Res Commun 123: 1062-1068

15. Dean PM, Matthews EK (1970) Electrical activity in pancreatic islet cells: effects of ions. J Physiol (London) 210: 265-275

16. Henquin JC, Lambert AE (1974) Cationic environment and dynamics of insulin secretion. II. Effect of a high concentration of potassium. Diabetes 23: 933-942

17. Herchuelz A, Thonnart N, Sener A, Malaisse WJ (1980) Regulation of calcium fluxes in pancreatic islets: the role of membrane depolarization. Endocrinology 107: 491-497

18. Deleers M, Ruysschaert JM, Malaisse WJ (1981) Glucose induces membrane changes detected by fluorescence polarization in endocrine pancreatic cells. Biochem Biophys Res Commun 98: 255-260

19. Kokubun S, Reuter H (1984) Dihydropyridine derivatives prolong the open state of Ca channels in cultured cardiac cells. Proc Natl Acad Sci USA 81: 4824-4827

20. Henquin JC, Meissner HP (1984) Significance of ionic fluxes and changes in membrane potential for stimulus-secretion coupling in the pancreatic B-cells. Experientia 40: 1043-1052

21. Prentki M, Wollheim CB (1984) Cytosolic free $\mathrm{Ca}^{2+}$ in insulin secreting cells and its regulation by isolated organelles. Experientia 40: $1052-1060$

22. Malaisse WJ, Sener A (1981) Calcium-antagonists and islet function. XII. Comparison between nifedipine and chemically related drugs. Biochem Pharmacol 30: 1039-1041

23. Malaisse WJ, Malaisse-Lagae F, Sener A (1984) Coupling factors in nutrient-induced insulin release. Experientia 40: 1035-1041

Received: 15 October 1984

and in revised form: 28 December 1984

Professor W.J. Malaisse

Laboratory of Experimental Medicine

Brussels Free University

115 Boulevard de Waterloo

B-1000 Brussels

Belgium 